\title{
References
}

Barnett, M., Kim, H., O’Donnell, M., Sitea, L. (2007) Peacebuilding: What Is in a Name? Global Governance: A Review of Multilateralism and International Organizations, 13(1): $35^{-58 .}$

Billaud, J. (2012) The Making of Modern Afghanistan: Reconstruction, Transnational Governance and Gender Politics in the New Islamic Republic. Anthropology of the Middle East, 7(1): 18-37.

De Lauri, A., Billaud, J. (2016) Humanitarian Theatre: Normality and the Carnivalesque in Afghanistan. In: De Lauri, A. ed. The Politics of Humanitarianism. Power, Ideology and Aid. I.B. Tauris.

Ferguson, J., Gupta, A. (2002) Spatializing States: Toward an Ethnography of Neoliberal Governmentality. American Ethnologist, 29(4): 981-1002.

Monsutti, A. (2012) Fuzzy Sovereignty: Rural Reconstruction in Afghanistan, between Democracy Promotion and Power Games. Comparative Studies in Society and History, 54(03): 563-591.

Orford, A. (2013) Moral Internationalism and the Responsibility to Protect. European Journal of International Law, 24(1): 83-108.

Rubin, B.R. (2006) Peace Building and State-Building in Afghanistan: Constructing Sovereignty for Whose Security? Third World Quarterly, 27(1): 175-185.

\section{Private Sector}

Private businesses started to become important agents in humanitarian aid after World War II. The nature of the post-World War II humanitarian aid from the United States to Europe was mostly dictated by the availability of food products and consumer goods from well-known American companies. This aid facilitated European integration into liberal capitalism and the introduction of consumerism to European societies (Wieters 2016). During the Cold War era, the Global South turned into a market space in which humanitarianism could dispose of Western agricultural and commodity surplus, and discipline so called Third World citizens as healthy labor force and customers for Western businesses (Sasson 2016; Wieters 2016). The second half of the Cold War era witnessed human rights activism that was concerned with growing business interests in the expanding humanitarian space, as well as the changing role of some humanitarian agencies in the business capitalization of emergency situations (Sasson 2016). Following the end of the Cold War, the siege of Sarajevo 
between 1992 and 1995 marked an interesting era in the history of expansionary capitalism that was facilitated by new communication/satellite technologies: humanitarian space opened by military intervention began to harbor black market activities (i.e. smuggling of aid items and sex trafficking), which produced private revenues and created a local business class before the eyes of aid workers, United Nations peacekeepers, foreign journalists, and academics (Andreas 2008).

A remarkable trait of the humanitarian wars in the 21st century was the extensive use of private military and security companies (PMSCs) in war zones such as Afghanistan and Iraq. There is a long history of private mercenaries in human warfare, but their redefinition as private contractors, their presence in the new humanitarian wars, and their diverse areas of activity have been particularly questionable, especially in terms of legitimacy in international law and the potential impact on human security (Gillard 2006; Spearin 2009). Liberal expectations (e.g. democracy, freedom, peace, economic development) from humanitarian interventions, wars on terror and international statebuilding attempts in countries such as Afghanistan, Iraq, Somalia and more recently Libya, Syria, and Yemen have failed dramatically; however, the presence of foreigners as armies, humanitarians, social entrepreneurs, and businesses is gaining a new discourse and format in the 21st century. The new trend refers to the growing, and increasingly more privatized, intersection between the processes of neoliberalism, securitization/militarization, and humanitarianism (Duffield 2014).

Financial institutions (from the World Bank to the German Development Bank), businesses (e.g. PMSCs, construction, food, logistics, energy, information, media, communication and digital technology firms), and social enterprises (e.g. digitalized entrepreneurial networks for refugees as part of resilience-building) are in active collaboration in areas of aid provision, disaster risk financing and management, service delivery, governance, reconstruction, stabilization, and development in post-disaster and conflict zones. At the same time, the nature of the international humanitarian regime has been changing with the gradual physical and financial withdrawal of the Western states and their humanitarian forces from the humanitarian space on the ground in dangerous war zones. Mark Duffield (2016: 149) argues that this is associated with anxiety and risk aversion in the Western world that is due to "policy failure, political push-back and humanitarian access denial." This kind of change entails (1) a new discourse centered around resilience-building among civilians in conflict zones to reduce dependency on humanitarian assistance (i.e. social entrepreneurship in capitalistic and neoliberal terms), (2) new technologies to continue distant monitoring and controlling of "people of 
concern" (i.e. remote management of humanitarian crisis and "bunkerization"), and (3) local and regional allies based in stable countries close to conflict regions who can be trusted to manage the conflict zones (e.g. the United Arab Emirates) (Duffield 2016; Ziadah 2019).

The recent international humanitarian engagement with Syrian refugees in the Middle East demonstrated some of the most privatized aspects of this evolution in the humanitarian regime. Automation of aid, cash-transfer programs, and informational mobile apps for Syrian refugees are promoted as examples of social entrepreneurship, innovation, and capacity-building for self-reliance. New surveillance technologies such as biometric registration, satellite sensing, mapping and networking software, and algorithmic analysis have become strategic tools to keep Syrian refugees in surveillance not only where they are currently, but also in places to which they may move in the future (Duffield 2016; Jacobsen 2017). The United Arab Emirates (UAE) is now playing the role of a facilitator and financier in this remote management mode of engagement with Syrians in need of humanitarian assistance. The UAE is the most skillful oilrich Gulf state in terms of commercializing humanitarian aid and incorporating it into supply chain capitalism through its ports and logistical capacities worldwide (Ziadah 2019). The UAE organizes the annual Dubai International Humanitarian Aid and Development Conference and Exhibition as an innovative platform for businesses to exhibit and advertise their products (e.g. tents, furniture, medicine, portable toilets, solar energy panels, and nutritional formulas) to potential state and non-state customers in the humanitarian sector. In this highly commercialized world of humanitarianism in the 21st century, it is not surprising that the busiest street with grocery stores and stands in the Zaatari Camp for Syrian refugees in Jordan is called Champs-Élysées, and Bulgari, the luxury jewelry brand, donated funds to a kindergarten inside the camp in 2018 (Nichol 2018).

\section{Deniz Gökalp}

\section{References}

Andreas, P. (2008) Blue Helmets and Black Markets. Cornell University Press.

Duffield, M. (2014) Global Governance and the New Wars: The Merging of Development and Security. Zed Books.

Duffield, M. (2016) The Resilience of the Ruins: Towards a Critique of Digital Humanitarianism. Resilience, 4(3): 147-165. 
Gillard, E.C. (2006) Business Goes to War: Private Military/Security Companies and International Humanitarian Law. International Review of the Red Cross, 88(863): 525-572.

Jacobsen, K.L. (2017) On Humanitarian Refugee Biometrics and New Forms of Intervention. Journal of Intervention and Statebuilding, $11(4): 529-551$.

Nichol, L. (2018) The Luxury Brand Giving Hope to Refugees this Ramadan. Harper's Bazaar-Arabia, May 17.

Sasson, T. (2016) Milking the Third World? Humanitarianism, Capitalism, and the Moral Economy of the Nestlé Boycott. The American Historical Review, 121(4): 1196-1224. Spearin, C. (2009) Private, Armed and Humanitarian? States, NGOs and International Private Security Companies and Shifting Humanitarianism. Security Dialogue, $39(4): 363-382$.

Wieters, H. (2016) Reinventing the Firm: From Post-War Relief to International Humanitarian Agency. European Review of History, 23(1-2): 116-135.

Ziadah, R. (2019) Circulating Power: Humanitarian Logistics, Militarism and the United Arab Emirates. Antipode: A Radical Journal of Geography, 51(5): 1684-1702.

\section{Professionalization}

Since the late 1990s, "the humanitarian sector has bureaucratized, rationalized, and professionalized with an unpredictable passion" (Barnett 2012: 188). Historically, the urge to professionalize was a reaction to the manifold shortcomings and failures of humanitarian organizations, such as the Rwandan genocide in 1994, which traumatized the humanitarian community and triggered a series of internal evaluations such as the one "held the year after [which] sadly concluded that, once political failure led to the crisis, many more lives could have been saved had humanitarian organizations better coordinated and acted more professionally" (Hilhorst 2002: 359). Since the 1990s, alongside increased budgets and an ever-growing number of people employed by humanitarian organizations, the importance of humanitarian intervention in global politics has risen.

Professionalization in humanitarian contexts has a set of meanings that all imply processes of specialization and diversification. First, professionalization refers to the acquirement of the necessary competencies and skills represented by the individual humanitarian. This points both to respective professions, such as engineering, nursing, logistics, and international humanitarian law in general, and also to specific training for the provision of professional assistance 